\title{
EFFECTS OF RIMONABANT ON ACTIVE AVOID- ANCE LEARNING IN BULBECTOMIZED RATS
}

\author{
Margarita Velikova ${ }^{1}$, Dobrinka Doncheva ${ }^{1}$, Roman Tashev ${ }^{2}$ \\ 1) Department of Physiology and pathophysiology, Medical University-Varna, \\ Bulgaria. \\ 2) Department of Pathophysiology, Medical University -Sofia, Bulgaria.
}

\begin{abstract}
The abnormal activity of endocannabinoid system has been implicated in the mechanisms of some psychiatric and neurological disorders. Olfactory bulbectomy (OBX) is an animal model of depression. We examined the effect of the CB1 antagonist Rimonabant (RIM) on the learning and memory processes of OBX rats tested in an active avoidance paradigm. RIM was administered by intragastric cannula to OBX rats once daily for 14 days. OBX rats were divided into three groups, and RIM was given before; immediately after; or 14 days after OBX. RIM showed a memory enhancing effect in the sham-operated rats and partially ameliorated the memory disturbances induced by the bulbectomy, given before OBX or 14 days after OBX. Only upon administration immediately after OBX, it prevented the development of the memory deficits. The study provides evidence that impaired endocannabinoid signalling may be involved in the development of cognitive deficits accompanying the OBX syndrome.
\end{abstract}

Keywords: Olfactory bulbectomy, cannabinoid receptor, memory, rat,

\section{INTRODUCTION}

Olfactory bulbectomy (OBX) is an experimental model of depression, which has also been proposed as a model of Alzheimer's disease [1,2]. The ablation of the olfactory bulbs $(O B X)$ in rodents induces a syndrome of physiological, neurochemical and behavioural changes which resemble clinical depression. The behavioural abnormalities include hyperlocomotion, increased aggression, cognitive impairments and others [3]. The removal of the olfactory bulbs and the following loss of connections between the bulbs and some brain regions result in structural, morphological and neurodegenerative changes in the brain. There are reports pointing to some similar mechanisms shared by both depressive disorders and Alzheimer's disease, related to the neurodegeneration and neuroinflammation in the brain [4]. The memory deficits are present in both depressive disorders and neurodegenerative diseases. Cognitive impairment is major symptom for Alzheimer's disease and a common symptom in depressive patients.

The endocannabinoid system (ECS) consists of the endogenous cannabinoids (endocannabinoids), the cannabinoid receptors and the enzymes involved in endocannabinoid metabolism [5]. The endocannabinoids act as neurotransmitters because they are released by neurons and are capable of activating membrane receptors. A key characteristic that distinguishes them from the other neurotransmitters is the retrograde mechanism of action. There are two types of cannabinoid receptors, CB1 and CB1, which are members of the $G$ protein-coupled receptor family. The CB1 receptor is the major type cannabinoid receptor in the brain, where it is expressed in both neurons and glial cells [6]. Endocannabinoid signalling affects many behavioural and physiological processes, including locomotion, feeding, nociception, memory, etc. In recent years, scientific research is carried out targeting the beneficial effects of endocannabinoid-based treatment in neurodegenerative disorders [7, 8, 9]. The cannabinoids have shown some beneficial effects in the treatment of neuropsychiatric symptoms in dementia $[10,11]$. In addition, they are affecting also cognition and their involvement in the mechanisms of memory impairment in disorders such as depression or Alzheimer's disease needs to be clarified [12]. The memory-impairing effect of the cannabinoids is associated mainly with activation of the cannabinoid CB1 receptors. In general, the inhibition of the ECS enhances learning and memory [13, 14]. However, the findings about the role of the CB1 receptor ligands on the cognitive processes remain contradictory.

The aim of our study was to investigate the effects of the CB1 antagonist Rimonabant administered intragastrically, on the learning and memory processes of OBX rats, tested in an active avoidance (TWAA) paradigm. In addition, we wanted to examine how the blockade of the $\mathrm{CB} 1$ receptors during different time intervals related to the bulbectomy (before, during or after the development of the depressive-like state) would affect the performance of OBX rats.

\section{MATERIALS AND METHODS}

Surgical procedures. Bilateral olfactory bulbectomy (OBX) was performed as previously described [15] (Marinov M). Rimonabant (RIM), SR141716A (Sanofi, France) was administered intragastrally for 14 days at a dose of $3 \mathrm{mg} / \mathrm{kg}$.

Animals. The experimental animals (male Wistar rats) were divided into four groups: 1/ Sham operated - RIM; 2/ 
RIM, administered prior to OBX surgery (14d RIM, OBX), 3/RIM, given immediately after OBX (OBX, 1-14d RIM); and 4/ RIM administered after development of the depressivelike state; (OBX, 14-28d RIM). In the 1-3 groups, the tests were performed 14 days after OBX, while in group 4 , tests were performed 28 days after OBX. The control groups, treated with saline included: sham-operated, $\mathrm{OBX}_{14}$, tested 14 days after $\mathrm{OBX}$, and $\mathrm{OBX}_{28}$, tested 28 days after $\mathrm{OBX}$. Following the termination of the experiments and immediately prior to sacrifice rats were injected with $1 \mathrm{ml} 2 \%$ fast green dye through the injection cannula for verification of cannula placement into ventriculus ventrolateralis dextra. The experiments were carried out according to the rules of the Ethics Committee of the Institute of Neurobiology, Bulgarian Academy of Sciences.

Two-way active avoidance test (TWAA, shuttle box). The animals were trained in a shuttle-box apparatus according to the method of Buresova and Bures [16]. The conditioned stimulus was the light of a $20 \mathrm{~W}$ bulb; the unconditioned stimulus was an electric non-scrambling shock (20$30 \mathrm{~V}, 0.5 \mathrm{~mA}$ for $3 \mathrm{~s}$ ) delivered through the grid floor. Two training trials on two consecutive days were carried out. The retention test (RT) was given 24 hours after the 2 nd training session. Each response of the rat ("avoidance", "escape" or "inadequate") was recorded. The primary measure of learning and memory in active avoidance task is an increase in avoidance responses.

Statistical Analysis. One-way ANOVA was used to analyse the data obtained for the number of avoidances for learning (1st and 2nd training day) and memory (retention test). Data were further analysed by post hoc SNK test, where appropriate. $\mathrm{P}$ values $<0.05$ were considered statistically significant.

Fig. 1. Effect of Rimonabant ( $3 \mathrm{mg} / \mathrm{kg}$ ), administered intragastrally for 14 days in OBX rats on learning and memory (1st training day) in TWAA test. $\mathrm{n}=12$.

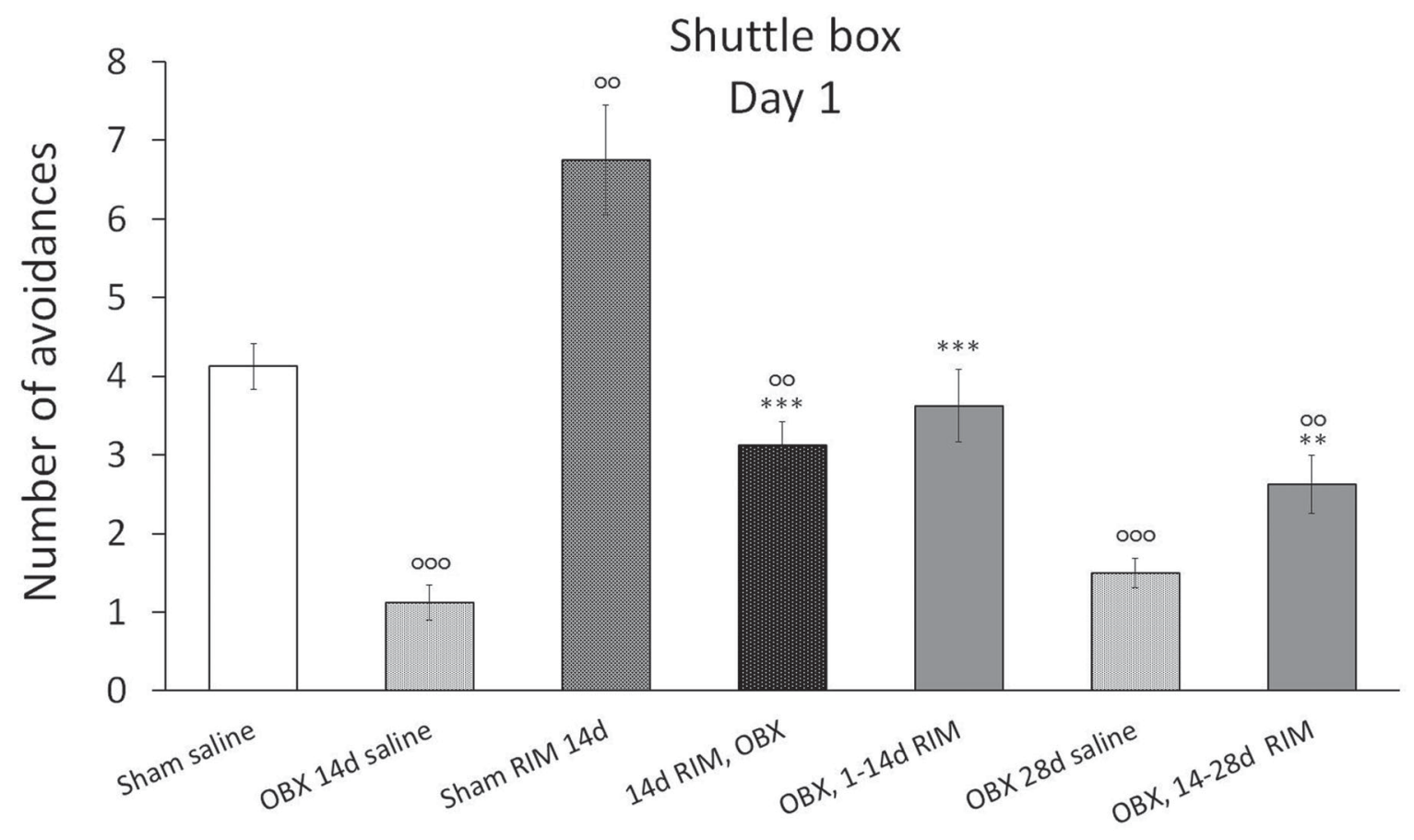

J of IMAB. 2020 Jan-Mar;26(1)

https://www.journal-imab-bg.org 
$* * \mathrm{P}<0.01, * * * \mathrm{P}<0.001-$ comparisons vs. saline-treated $\mathrm{OBX}$ controls. ${ }^{00} \mathrm{P}<0.01,{ }^{000} \mathrm{P}<0.001-$ comparisons vs. saline-treated sham controls. Means ( \pm S.E.M.) are presented.

Fig. 2. Effect of Rimonabant ( $3 \mathrm{mg} / \mathrm{kg}$ ), administered intragastrally for 14 days in OBX rats on learning and memory (2nd training day) in TWAA test. $\mathrm{n}=12$.

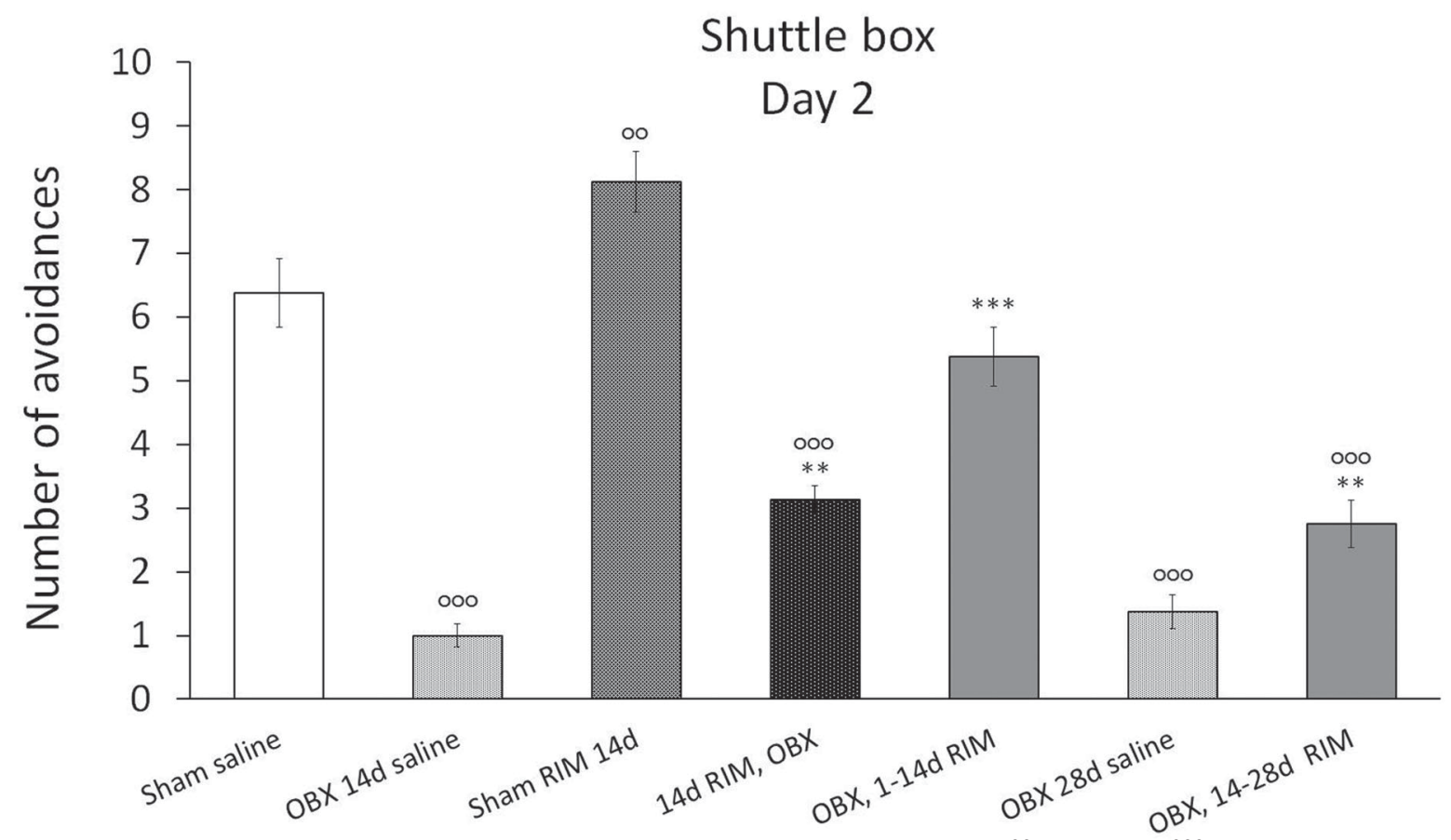

$* * \mathrm{P}<0.01, * * * \mathrm{P}<0.001-$ comparisons vs. saline-treated $\mathrm{OBX}$ controls. ${ }^{00} \mathrm{P}<0.01,{ }^{000} \mathrm{P}<0.001-$ comparisons vs. saline-treated sham controls. Means ( \pm S.E.M.) are presented.

Fig. 3. Effect of Rimonabant ( $3 \mathrm{mg} / \mathrm{kg}$ ), administered intragastrally for 14 days in OBX rats, on learning and memory (retention test) in TWAA test. $\mathrm{n}=12$.

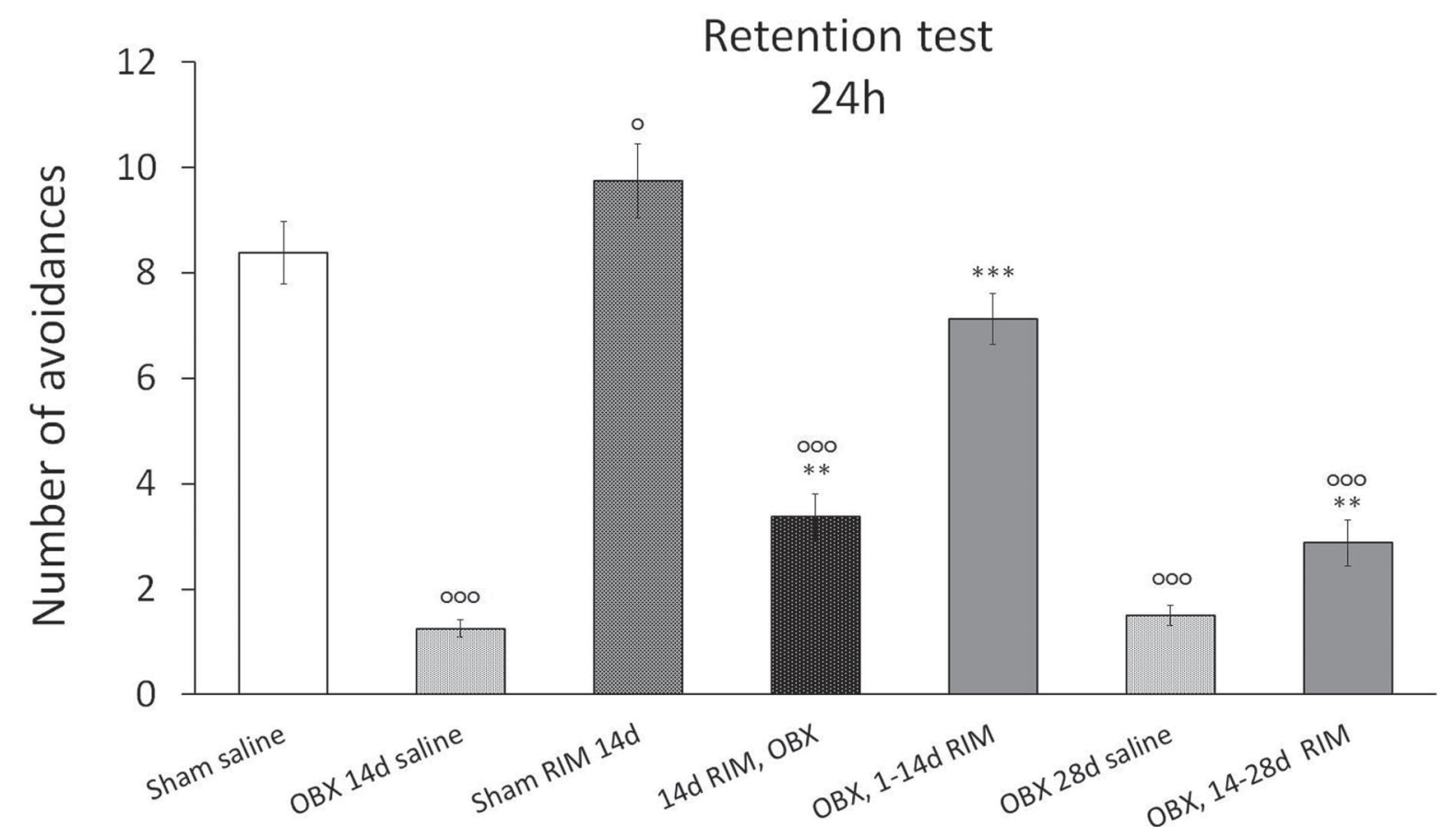

$* * \mathrm{P}<0.01, * * * \mathrm{P}<0.001$ - comparisons vs. saline-treated $\mathrm{OBX}$ controls; ${ }^{0} \mathrm{P}<0.05,{ }^{000} \mathrm{P}<0.001-$ comparisons vs. saline-treated sham controls. Means ( \pm S.E.M.) are presented. 
The influence of the CB1 receptor ligands on learning and memory processes has been investigated with various animal models and clinical tests. However, the data remain controversial - modulation of cannabinoid receptors may produce either improvement or attenuation of memory [17]. The contradictory results have been related to the different behavioural patterns and experimental conditions used (dose, way and time of administration of the ligands, types of behavioural tests, etc.).

We observed that rimonabant (SR141716A), given intragastrically before the training, showed a tendency to improve the performance of the sham-operated rats in the TWAA test. The effects of CB1 receptor antagonists applied in memory tests are ambiguous. There is evidence that acute administration of rimonabant disturbs memory in some animal models, while pretreatment with another CB1 antagonist AM 251 prevented the development of memory impairment induced by a CB1 receptor agonist oleamide in an inhibitory avoidance test $[18,13]$. Now, we support the reports, where the systemic application of SR141716A before the training sessions improved the memory processes in rodents, tested by radial arm maze, social recognition memory test, and short-term memory test [19, 20, 21, 22].

The olfactory bulbectomy model has been proposed as a useful method for investigating the mechanisms underlying depression and Alzheimer's disease. The removal of the olfactory bulbs in rodents results in disruption of neuronal connections between the olfactory bulbs and structures of the limbic system, thus resembling the neurodegenerative events in patients with depressive disorder or with Alzheimer's disease $[1,23]$. As Kelly åt al. described the OBX syndrome, all behavioural deficits are present two weeks after surgery and the memory impairment is long lasting [3]. Both the abilities to acquire and to retrieve memory are impaired after OBX surgery. Bulbectomized rats show deficits in different learning and memory tests, including passive and active avoidance paradigms [24, 25, 26].

The cognitive deficit is considered a result of the neurodegeneration, occurring secondary to the removal of the olfactory bulbs. The disturbed function of the ECS in OBX rats is likely to contribute to memory impairment, by affecting the activity of some neurotransmitter systems [27, 28]. In our previous study, we observed that SR141716, applied i.c.v failed to produce any significant effects in the TWAA, às compared to the controls, while the CB1 agonist HU 210 improved the performance in the OBX rats [15]. In order to evaluate the implication of the endocannabinoid signalling in distinct stages of the development of OBX syndrome, we examined the effect of CB1 receptor antagonist Rimonabant, applied subchronically, during different time intervals (before surgery, immediately post-surgery and 14 days post-surgery) on the performance of OBX rats in the TWAA test.

Rimonabant given before OBX or 14 days post-surgery improved the scores in both groups; however, it failed to reverse completely the OBX-induced cognitive impairment. Our data are in accordance with the reported positive effect of chronic treatment with rimonabant on acquisition learning in zebrafish [29].

Different brain structures contribute to the animal behaviour in the active avoidance conditioning. The performance of the rodents in the aversive conditioning tasks is difficult for interpretation as far as any factors (e.g. locomotor activity, state of anxiety, type of the stimulus, brain area that is stimulated, etc.) tend to influence the animal behaviour. In the present study, we observed that only upon administration immediately after OBX (1-14d), RIM was able to prevent the development of some detrimental changes in the brain and thus the performance of the OBX rats in the shuttle box was not impaired. The results suggest that the time interval for application, regarding the surgery procedure for the removal of the bulbs also seems to be a contributing factor.

In rodents, hippocampal cannabinoid receptors have been implicated in the impairment of learning and memory. The memory disturbance induced by a systemic administration of tetrahydrocannabinol was abolished by the intrahippocampal infusion of rimonabant [30]. An explanation of the memory disturbing effects of $\mathrm{CB} 1$ receptor activation might be the inhibited release of acetylcholine or gamma-aminobutyric acid (GABA) in the hippocampus or the interference with the NMDA glutamate receptor activity $[31,32,33]$.

\section{CONCLUSION}

Among the many factors that tend to affect the rats performance in the active avoidance test, the time interval for application also seems to be a contributing factor. The application of CB1 antagonist immediately after bulbectomy counteracted the bulbectomy-induced learning and memory impairment. Our results suggest that the impaired endocannabinoid signalling may be involved in the development of cognitive deficits accompanying the OBX syndrome.

\section{REFERENCES:}

1. Song C, Leonard BE. The olfactory bulbectomised rat as a model of depression. Neurosci Biobehav Rev. 2005; 29(4-5):627-47. [PubMed]

2. Yehuda S, Rabinovitz S. Olfactory bulbectomy as a putative model for Alzheimer: The protective role of essential fatty acids. Pharma Nutri- tion. 2014; 2:12-14.

3. Kelly JP, Wrynn AS, Leonard BE. The olfactory bulbectomized rat as a model of depression: an update. Pharmacol Ther. 1997; 74(3):299316. [Pubmed] [Crossref]

4. Wuwongse S, Chang RC, Law AC. The putative neurodegenerative links between depression and Alzheimer's disease. Prog Neurobiol. 2010 Aug;91(4):362-75. [PubMed]

5. Mechoulam R, Parker LA. The endocannabinoid system and the brain. Annu Rev Psychol. 2013; 64:21-47. [PubMed] [Crossref]

6. Pertwee RG, Howlett AC, Abood 
ME, Alexander SP, DiMarzo V, Elphick $\mathrm{MR}$, et al. International Union of Basic and Clinical Pharmacology. LXXIX. Cannabinoid receptors and their ligands:beyond CB1 and CB2. Pharmacol Rev 2010 Dec;62(4):588631. [PubMed] [Crossref]

7. Cao C, Li Y, Liu H, Bai G, Mayl J, Lin X, et al. The potential therapeutic effects of THC on Alzheimer's disease. J Alzheimers Dis. 2014; 42(3): 973-84. [PubMed] [Crossref]

8. Fernandez-Ruiz J, Romero J, Ramos JA. Endocannabinoids and Neurodegenerative Disorders: Parkinson's disease, Huntington's Chorea, Alzheimer's Disease, and Others. Handb Exp Pharmacol. 2015; 231: 233-59. [PubMed]

9. Lim K, See YM, Lee J. A Systematic Review of the Effectiveness of Medical Cannabis for Psychiatric, Movement and Neurodegenerative Disorders. Clin Psychopharmacol Neurosci. 2017; 15(4): 301-12. [PubMed] [Crossref]

10. Herrmann N, Ruthirakuhan M, Gallagher D, Verhoeff NPLG, Kiss A, Black SE, et al. Randomized placebocontrolled trial of nabilone for agitation in Alzheimer's disease. Am J Geriatr Psychiatry. 2019 Nov;27(11): 1161-1173. [PubMed] [Crossref]

11. van den Elsen GA, Ahmed AI, Verkes RJ, Kramers C, Feuth T, Rosenberg PB, et al. Tetrahydrocannabinol for neuropsychiatric symptoms in dementia: a randomized controlled trial Neurology. 2015 Jun 9; 84(23):2338-46. [PubMed] [Crossref]

12. Stumm C, Hiebel C, Hanstein R, PurrioM, Nagel H, Conrad A, et al. Cannabinoid receptor 1 deficiency in a mouse model of Alzheimer's disease leads to enhanced cognitive impairment despite of a reduction in amyloid deposition. Neurobiol Aging. 2013 Nov;34(11):2574-84. [PubMed] [Crossref]

13. Kruk-Slomka M, Dzik A, Budzynska B, Biala G. Endocannabinoid System: the Direct and Indirect Involvement in the Memory and Learning Processes-a Short Review. Mol Neurobiol. 2017 Dec;54(10): 8332-47. [PubMed] [Crossref]

14. Riedel G, Davies S. Cannabinoid function in learning, in: Handbook of experimental pharmacol- ogy, Eds: Barrett, James E. (2005) Springer; 168, pp.:445-77. [PubMed]

15. Marinov $M$, Ivanova $M$, Belcheva S, Belcheva I, Tashev R. Effects of acutely applied cannabinoid CB1 ligands on learning and memory in rats with a model of depression. $C$ $R$ Acad Bulg Sci. 2013; 66(9):133138.

16. Buresova O, Bures J. Capter 3. In: Techniques and Basic Experiments for the Study of Brain and Behavior. Bures J, Buresova O, Huston JP, editors. Elsevier Sci Publ; 2nd Revised \& enlarged edition. 1983 June; pð.:135208.

17. Kruk-Slomka M, BoguszewskaCzubara A, Slomka T, Budzynska B, Biala G. Correlations between the memory-related behavior and the level of oxidative stress biomarkers in the mice brain provoked by an acute administration of CB receptor ligands. Neural Plast 2016; 9815092. [PubMed] [Crossref]

18. Adam AS, Wenger T, Csillag A. The cannabinoid $\mathrm{CB} 1$ receptor antagonist rimonabant dose-dependently inhibits memory recall in the passive avoidance task in domestic chicks (Gallus domesticus). Brain Res Bull. 2008 Jun 15;76(3):272-4. [PubMed] [Crossref]

19. Deadwyler SA, Goonawardena AV, Hampson RE. Short-term memory is modulated by the spontaneous release of endocannabinoids: evidence from hippocampal population codes. Behav Pharmacol. 2007; 18(5-6): 571-80. [PubMed]

20. Lichtman AH. SR 141716A enhances spatial memory as assessed in a radial-arm maze task in rats. Eur $J$ Pharmacol. 2000 Sep 15;404(12):175-9. [PubMed] [Crossref]

21. Terranova JP, Storme JJ, Lafon N, Perio A, Rinaldi-Carmona M, Le Fur $\mathrm{G}$, et al. Improvement of memory in rodents by the selective CB1 cannabinoid receptor antagonist, SR 141716. Psychopharmacology (Berl). $1996 \mathrm{Jul}$; 126(2):165-72. [PubMed] [Crossref]

22. Wolff MC, Leander JD. SR141716A, a cannabinoid CB 1 receptor antagonist, improves memory in a delayed radial maze task. Eur $J$ Pharmacol. 2003 Sep 23;477(3):21317. [PubMed] [Crossref]

23. Hendriksen $\mathrm{H}$, Korte SM,
Olivier B, Oosting RS. The olfactory bulbectomy model in mice and rat: one story or two tails? Eur J Pharmacol. 2015 Apr 15;753:105-13. [PubMed] [Crossref]

24. King MG, Cairncross KD. Effects of olfactory bulb section on brain noradrenaline, corticosterone and conditioning in the rat. Pharmacol Biochem Behav. 1974 May;2(3):347-53. [PubMed] [Crossref]

25. Tashev $\mathrm{R}$, Ivanova $\mathrm{M}$, Toromanov T, Marinov M, Belcheva S, Belcheva I. Olfactory bulbectomy impairs active and passive avoidance learning in rats. Comptes rendus de l'Acadeimie bulgare des sciences. 2010; 63(4):617-22.

26. van Riezen H, Schnieden H, Wren AF. Olfactory bulb ablation in the rat: behavioural changes and their reversal by antidepressant drugs. $\mathrm{Br} J$ Pharmacol. 1977 Aug;60(4):521-8. [PubMed] [Crossref]

27. Eisenstein SA, Clapper JR, Holmes PV, Piomelli D, Hohmann AG. A role for 2-arachidonoylglycerol and endocannabinoid signaling in the locomotor response to novelty induced by olfactory bulbectomy. Pharmacol Res. 2010 May; 61(5):419-29. [PubMed] [Crossref]

28. Smaga I, Jastrzêbska J, Zaniewska M, Bystrowska B, Gawliñski D, Faron-Górecka A, et al. Changes in the Brain Endocannabinoid System in Rat Models of Depression. Neurotox Res 2017 Apr; 31(3):421-35. [PubMed] [Crossref]

29. Ruhl T, Moesbauer K, Oellers $\mathrm{N}$, von der Emde G. The endocannabinoid system and associative learning and memory in zebrafish. Behav Brain Res. 2015 Sep 1;290:61-9. [PubMed] [Crossref]

30. Wise LE, Thorpe AJ, Lichtman AH. Hippocampal CB(1) Receptors Mediate the Memory Impairing Effects of Delta(9)-tetrahydrocannabinol. Neuropsychopharmacology. 2009 Aug; 34(9):2072-80. [PubMed] [Crossref]

31. Gifford AN, Bruneus M, Gatley SJ, Volkow ND. Cannabinoid receptormediated inhibition of acetylcholine release from hippocampal and cortical synaptosomes. Br J Pharmacol. 2000 Oct;131(3):645-50. [PubMed] [Crossref]

32. Katona I, Sperlagh B, Sik A, 
Kafalvi A, Vizi ES, Mackie K, et al. Presynaptically located CB1 cannabinoid receptors regulate GABA release from axon terminals of specific hippocampal interneurons. J Neurosci. 1999 Jun 1;19(11):4544-58. [PubMed] [Crossref]

33. Liu Q, Bhat M, Bowen WD,
Cheng J. Signaling pathways from cannabinoid receptor- 1 activation to inhibition of N-methyl-D-aspartic acid mediated calcium influx and neurotoxicity in dorsal root ganglion neurons. J Pharmacol Exp Ther. 2009 Dec;331(3):1062-70. [PubMed]

Please cite this article as: Velikova M, Doncheva D, Tashev R. Effects of Rimonabant on active avoidance learning in bulbectomized rats. J of IMAB. 2020 Jan-Mar;26(1):2936-2941. DOI: https://doi.org/10.5272/jimab.2020261.2936

Received: 13/01/2020; Published online: 24/02/2020

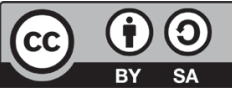

Address for correspondence:

Assoc. prof. Margarita Velikova, MD, PhD

Department of Physiology and Pathophysiology, Medical University, 55, M. Drinov Str., 9002 Varna, Bulgaria.

E-mail: msvelikova@yahoo.com, 